\title{
Effect of hypobaric storage on quality, antioxidant enzyme and antioxidant capability of the Chinese bayberry fruits
}

Hangjun Chen ${ }^{1}$, Hailong Yang ${ }^{2}$, Haiyan Gao ${ }^{1 *}$, Jie Long ${ }^{1}$, Fei Tao ${ }^{1}$, Xiangjun Fang ${ }^{1}$ and Yueming Jiang ${ }^{3 *}$

\begin{abstract}
Background: The Chinese bayberry (Myrica rubra Sieb. and Zucc.) is a subtropical fruit native to China, with unique flavor, sweet and sour taste, and high nutrition and health values. The fruit is highly perishable and susceptible to mechanical injury, physiological deterioration and fungal decay once harvested. This study was to investigate the effect of hypobaric storage on the quality of Chinese bayberry fruit and then develop storage technology to prolong the supply of the fruit.

Results: The fruit stored under hypobaric conditions exhibited lower decay, higher titratable acidity and total phenolics compared with those stored under normal atmospheric conditions. Hypobaric storage significantly reduced malonaldehyde accumulation, respiratory rate and maintained high catalase and peroxidase activities of Chinese bayberry fruit. Ferric reducing antioxidant power was also higher in the fruit stored under hypobaric condition than those under normal atmospheric conditions.
\end{abstract}

Conclusion: Hypobaric storage improved the metabolism, antioxidant system and postharvest quality of Chinese bayberry fruit and provided an effective alternative method to prolong the storage life of this fruit.

Keywords: Chinese bayberries, Hypobaric storage, Quality, Antioxidant enzymes, Antioxidant capacity

\section{Background}

The Chinese bayberries (Myrica rubra Sieb. and Zucc.) are a subtropical fruit native to China. In terms of the unique flavor, sweet and sour taste, attractive red color, and high nutrition and health values; Chinese bayberries have been cultivated in eastern and southern China for more than 2000 years and are being introduced to other countries. The fruit mature in early summer season and are praised as the "precious southern Yangtze fruit of early summer" [1-3]. The Chinese bayberries contain abundant anthocyanins, flavonoids and other phenolic compounds, with high antioxidant capacity [3-5]. Unfortunately, the fruit are highly perishable and susceptible to mechanical injury, physiological deterioration and fungal decay, resulting in a short postharvest life of 1-2 days at ambient temperature [6]. Some methods, including low temperature storage

\footnotetext{
* Correspondence: spsghy@163.com; ymjiang@scbg.ac.cn

${ }^{1}$ Food Science Institute, Zhejiang Academy of Agricultural Sciences,

Hangzhou 310021, China

${ }^{3}$ South China Botanical Garden, Chinese Academy of Sciences, Guangzhou 510650, China

Full list of author information is available at the end of the article
}

$[7,8]$, high oxygen atmosphere treatment $[9,10]$, hot air treatment [6,11], combined treatment of ethanol vapor with hot air [12], have been used to investigate postharvest physicochemical and physiological attributes and storage life extension of the Chinese bayberry fruit. However, due to the delicate nature of the fruit, poor handling practices and inadequate storage facilities, the shelf life of the Chinese bayberry is still short, which markedly limits its market. As this fruit is further commercially developed, it is important to develop effective storage methods to prolong the shelf life.

Among these techniques for controlling postharvest decay of fruit and vegetables, the use of sub-atmospheric pressure exhibits a potential to store fresh Chinese bayberries. Hypobaric storage can quickly remove heat and reduce oxygen level [13]. During storage, water spray could be used to solve the problem of insufficient environmental humidity [14]. It has been reported that hypobaric treatment delayed ripening of some climatic fruits such as apples, avocados, bananas, mangoes, tomatoes, apple, sweet cherry, asparagus, and peach [14-17]. With the development of storage technology, different models
(C) Chemistry Central

C 2013 Chen et al.; licensee Chemistry Central Ltd. This is an Open Access article distributed under the terms of the Creative Commons Attribution License (http://creativecommons.org/licenses/by/2.0), which permits unrestricted use, distribution, and reproduction in any medium, provided the original work is properly cited. 
of hypobaric storage machine have been developed and tested for the storage of fruit and vegetables. However, little information is available in the literature about this storage technology for Chinese bayberry fruit.The objective of this present study was to investigate the effects of different hypobaric storage treatments on postharvest life and quality of the Chinese bayberry fruit. The antioxidant enzyme activities and antioxidant capacity were also evaluated. Finally, the optimal condition of hypobaric storage to extend the shelf life of the Chinese bayberry fruit was determined.

\section{Results and discussion}

\section{Effect of hypobaric storage on fruit decay of Chinese bayberries}

Chinese bayberries are highly perishable and susceptible to mechanical injury, physiological deterioration and fungal decay [6]. The fruit stored under normal atmospheric pressure (control) showed 37.5\% decay after 6 days of storage, but the fruit stored under $85 \pm 5,55 \pm 5$ and $15 \pm 5 \mathrm{kPa}$ exhibited 7.25, 5.0 and $6.25 \%$ decay, respectively. As shown in Figure 1, the decay severity increased gradually with increasing storage. After 15 days of storage, the decay percentages of the Chinese bayberries stored under 101.3, 85 \pm 5 , $55 \pm 5$ and $15 \pm 5 \mathrm{kPa}$ were $81.2,31.25,18.75$ and $25 \%$, respectively. It was reported that low pressure treatment discouraged commodity deterioration caused by bacteria and fungi and was capable of killing many insects infesting agricultural commodities [18]. Romanazzi, et al. [19] reported hypobaric treatment was effective in reducing decay of sweet cherries, strawberries and table grapes. The present study showed that hypobaric storage was an effective method to reduce decay of the Chinese bayberry. Among these four treatments, it was found that application of $55 \pm 5$ $\mathrm{kPa}$ was the optimal to reduce the fruit decay.

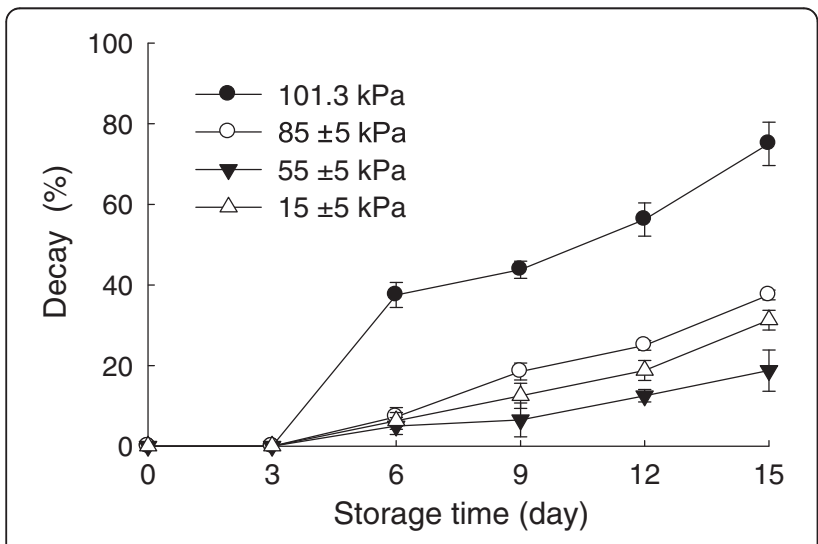

Figure 1 Effects of hypobaric storage on fruit decay of the Chinese bayberry. Fruits were stored at $1 \pm 0.5^{\circ} \mathrm{C}$ and $85-90 \%$ relative humidity under different atmosphere pressures.

\section{Effects of hypobaric storage on skin colour and pulp TSS and TA}

The Chinese bayberry fruit of most cultivars are red or dark-red colour due to the presence of anthocyanins [3-5]. The major anthocyanin in the Chinese bayberry fruit was identified to be cyanidin-3-glucoside which represented more than $95 \%$ of the total anthocyanins [4]. Skin colour is an important index to evaluate the quality of the Chinese bayberry fruit. As shown in Figure $2 \mathrm{~A}$ and $2 \mathrm{~B}, \mathrm{~L}^{*}$ value increased while $\mathrm{a}^{*}$ value of the fruit decreased gradually during storage. However, no significant $(\mathrm{P}<0.05)$ differences in the skin colour were observed among these different pressure treatments after 15 days of storage.

TSS content of the Chinese bayberry fruit decreased during storage (Figure $2 \mathrm{C}$ ) but no significant $(\mathrm{P}<0.05)$ differences existed among the different pressure treatments. Figure 2D presented TA content of the Chinese bayberries. The TA content decreased gradually during storage. By the end of storage, TA content decreased to 11.6, $5.0,8.7$ and $6.9 \%$ under $101.3,85 \pm 5,55 \pm 5$ and $15 \pm 5 \mathrm{kPa}$ conditions, respectively. The changes in TA and TSS contents could be associated with the metabolic activity and respiratory rates of the fruits. Corey, et al. [20] reported that respiration rate of lettuce decreased by $40 \%$ when stored in a chamber at a pressure of $51 \mathrm{kPa}$. The results in this study could be explained by a lower respiratory rate (Figure 3A), which caused less depletion of sugars and acids when fruit was stored at lower pressures.

\section{Effects of hypobaric storage on respiration and ethylene production rates}

The respiratory rate of the Chinese bayberry fruit was around $9 \mathrm{mg} \mathrm{CO} \mathrm{Kg}^{-1} \mathrm{~h}^{-1}$ before storage and decreased gradually with increasing storage (Figure $3 \mathrm{~A}$ ). By the end of storage, respiratory rates of the Chinese bayberry stored under 101.3, 85 \pm 5 , and $55 \pm 5 \mathrm{kPa}$ conditions were 4.75 , 3.72 , and $3.16 \mathrm{mg} \mathrm{CO}_{2} \mathrm{~kg}^{-1} \mathrm{~h}^{-1}$, respectively. The respiratory intensity of the fruit under hypobaric storage was significantly $(\mathrm{P}<0.05)$ inhibited, as compared with under normal atmospheric pressure. Ethylene production rates of the Chinese bayberries decreased gradually, from 0.52 before storage to $0.042 \mu \mathrm{L} \mathrm{kg}^{-1} \mathrm{~h}^{-1}$ by the end of storage (Figure 3B). However, no significant differences in ethylene production rates were observed between the hypobaric storage and normal storage.

It was reported that hypobaric packaging reduced the respiration rates of strawberry and curled lettuce [21]. He et al. [22] also reported that hypobaric storage conditions could reduce greatly the ethylene production rate in both lettuce and wheat. The removal of ethylene production could delay senescence of fruits and vegetables and, indirectly, reduce their susceptibility to pathogens [19]. The inhibition of the respiratory rate in the Chinese bayberry fruit by hypobaric treatment can help to extend the shelf life. 

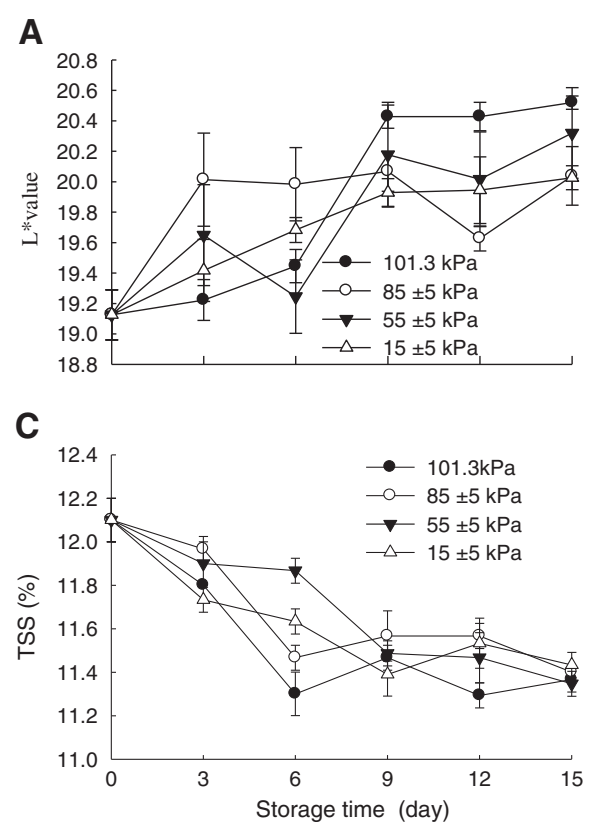

B

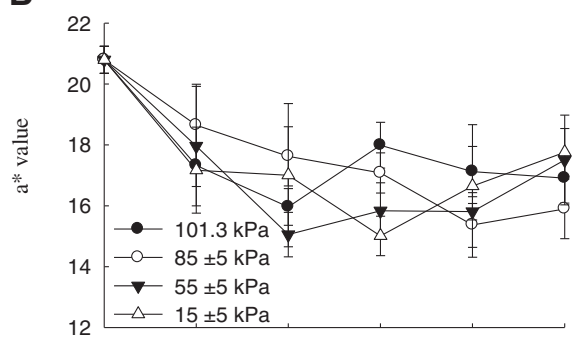

D

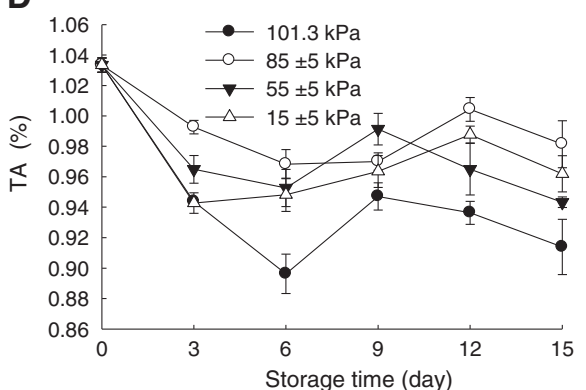

Figure 2 Effects of hypobaric storage on skin colour (A: $L^{*}$ value, B: $a^{*}$ value) and contents of total soluble solids (C) and titratable acidity (D) of the Chinese bayberry fruit. Fruits were stored at $1 \pm 0.5^{\circ} \mathrm{C}$ and $85-90 \%$ relative humidity under different atmosphere pressures.

\section{Effect of hypobaric storage on malondialdehyde (MDA) content}

MDA is considered to be an indicator of membrane lipid peroxidation caused by oxidative stress. As shown in Figure 4, MDA content of the Chinese bayberry fruit under normal pressure condition rose gradually during storage. MDA contents of fruit stored under 101.3, 85 \pm 5 , $55 \pm 5$ and $15 \pm 5 \mathrm{kPa}$ conditions after 15 days of storage were $5.08 \times 10^{-3}, 4.51 \times 10^{-3}, 4.21 \times 10^{-3}$ and $4.53 \times 10^{-3} \mu \mathrm{mol}$ $\mathrm{g}^{-1}$ on fresh weight (FW) basis, respectively, which exhibited that hypobaric storage inhibited the accumulation of MDA. Similar results were obtained by Li et al. [14] who reported that hypobaric storage could reduce MDA accumulation and retard senescence in asparagus.

\section{Effect of hypobaric storage on antioxidant enzyme activities}

The accumulation of reactive oxygen species, such as superoxide, hydrogen peroxide, and the hydroxyl radical, causes plant tissue damage and reduces the storage quality and marketability of fruits and vegetables [23]. Antioxidative enzymes such as catalase (CAT) and peroxidase (POD) play an important role to scavenge reactive oxygen. As shown in Figure 5A and 5B, CAT activities of the Chinese bayberry fruit tended to change differently at various pressure conditions, but the fruit stored under the hypobaric condition exhibited a higher activity than those stored under the normal pressure condition. For POD activity, hypobaric storage condition maintained a significantly
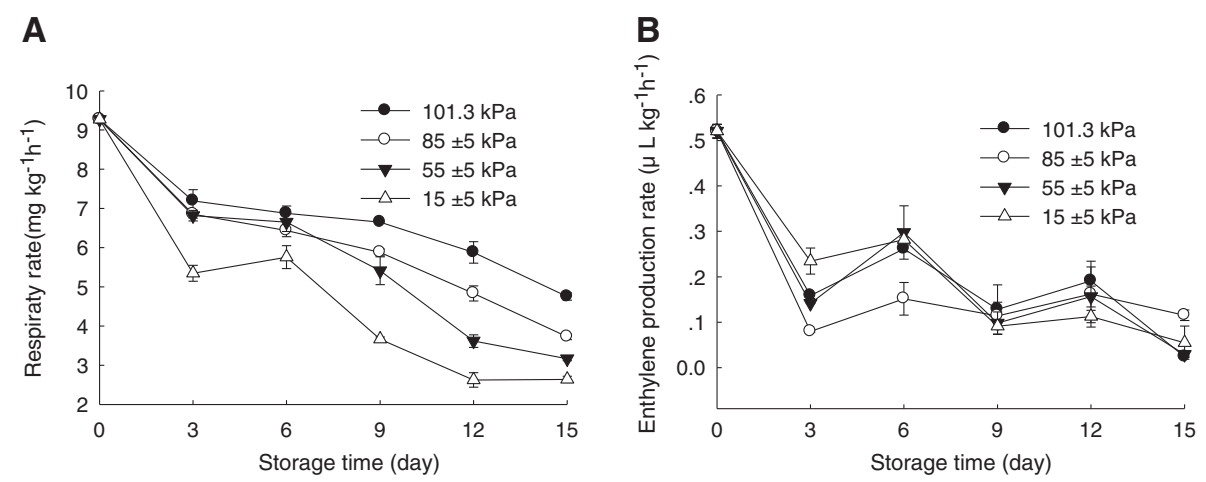

Figure 3 Effects of hypobaric storage on rates of respiration (A) and ethylene production (B) of the Chinese bayberry fruit. Fruit were stored at $1 \pm 0.5^{\circ} \mathrm{C}$ and $85-90 \%$ relative humidity under different atmosphere pressures. 


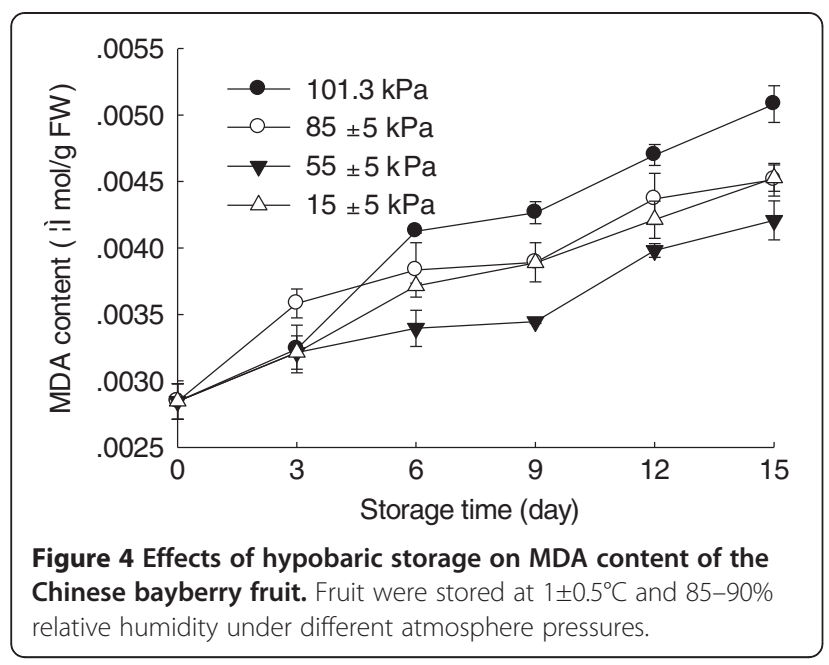

$(\mathrm{P}<0.05)$ higher activity compared with the normal atmospheric condition. Chen et al. [17] reported that hypobaric storage maintained high CAT activity in peach. In this study, application of hypobaric storage enhanced CAT and POD activities and, thus, reduced membrane lipid peroxidation of the Chinese bayberry (Figure 4).

\section{Effects of hypobaric storage on total phenolic content and total antioxidant capacity}

Phenolic compounds including flavonoids and phenolic acids are known to be responsible for antioxidant capacity in fruits. The Chinese bayberries are rich in phenolic compounds and exhibit high antioxidant activity $[3,4,24]$. As shown in Figure $6 \mathrm{~A}$, total phenolic content of the fruit increased during storage. However, no significant differences were observed among these different pressure treatments within the first 3 days of storage. The total phenolic content of the fruit under the hypobaric conditions after 3 days of storage rose rapidly, and then reached 1.083, 0.999, and $1.134 \mathrm{mg} \mathrm{g}^{-1} \mathrm{FW}$ when fruit were stored at $85 \pm 5,55 \pm 5$ and $15 \pm 5 \mathrm{kPa}$ after 15 days of storage, respectively, but only $0.892 \mathrm{mg} \mathrm{g}^{-1} \mathrm{FW}$ at $101.3 \mathrm{kPa}$, which indicated that hypobaric storage was more effective to maintain phenolic content of the fruit. In similarity with the change in total phenolic content, reducing power of fruit rose gradually during storage (Figure 6B). In this study, the fruit stored under $55 \pm 5 \mathrm{kPa}$ showed the strongest ferric reducing antioxidant power. However, ferric reducing antioxidant power (FRAP) was not correlated well with the total phenolic contents. It has been reported that different antioxidant activity could be due to the difference in phenolic constituents [25].

\section{Materials and methods}

\section{Fruit materials}

The Chinese bayberries (Myrica rubra Sieb. \& Zucc., cv. Dongkui) fruit were harvested manually from a commercial orchard in Xianju county of Zhejiang Province, China on June 28, 2010, and then transported to the laboratory by a refrigerated car within 3 hours. Fruit were selected for uniformity of shape and color and the blemished and diseased fruit were discarded.

\section{Fruit treatments}

Fruit treatments were performed in a hypobaric storage system with storage chambers whose pressure could be set independently (Model XL-5, Xianlv Low-pressure Fresh Keeping Equipment Co. Ltd., Shanghai, China). Each replicate containing $2 \mathrm{~kg}$ fruits was put in a plastic basket and placed into the hypobaric chamber. The applied pressures were set to be $85 \pm 5,55 \pm 5$ and $15 \pm 5 \mathrm{kPa}$, respectively. The normal atmospheric pressure (101.3 $\mathrm{kPa})$ was used as control. These fruit were stored at $1 \pm 0.5^{\circ} \mathrm{C}$ and $85-90 \%$ relative humidity (RH). Fruit samples were taken for analysis every 3 days in the storage period of 15 days.

\section{Evaluations of fruit decay and skin colour}

Fruit decay was visually evaluated. Fruit with visible mold growth with about $2 \%$ of the surface affected was
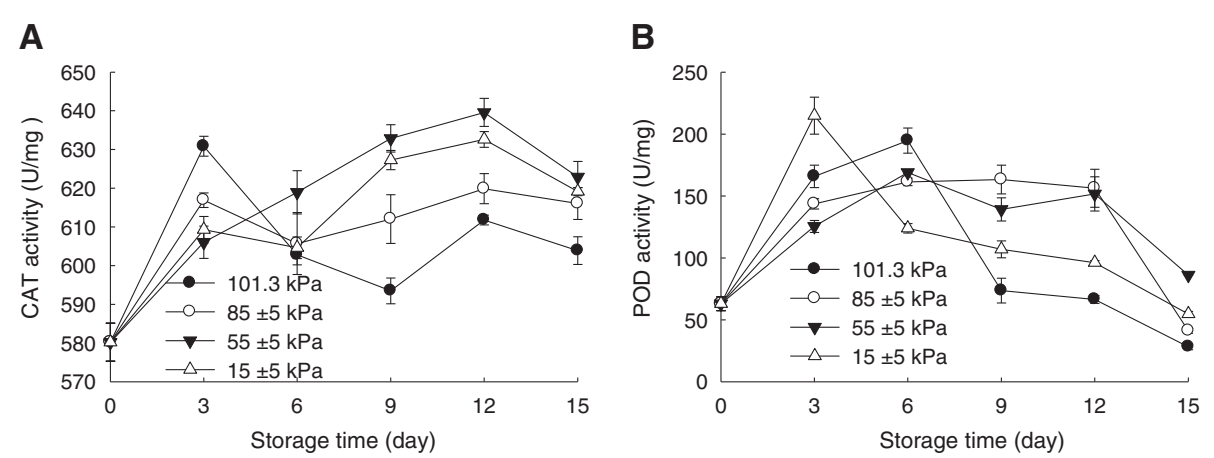

Figure 5 Effects of hypobaric storage on activities of CAT (A) and POD (B) of the Chinese bayberry fruit. Fruit were stored at $1 \pm 0.5^{\circ} \mathrm{C}$ and $85-90 \%$ relative humidity under different atmosphere pressures. 
A

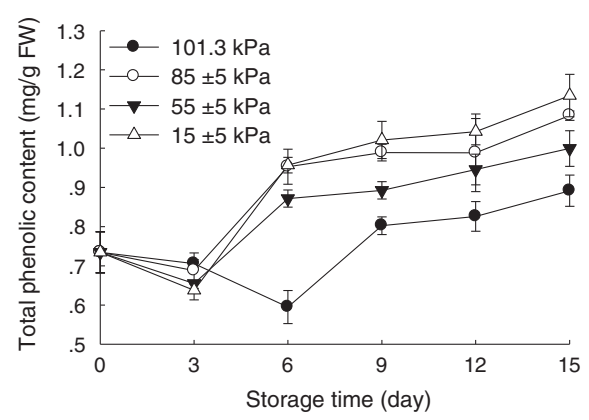

B

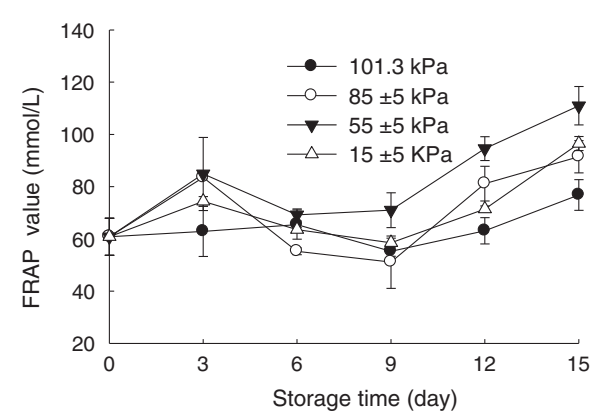

Figure 6 Effects of hypobaric storage on total phenolic content (A) and total antioxidant capacity (B) of the Chinese bayberry fruit. Fruit were stored at $1 \pm 0.5^{\circ} \mathrm{C}$ and $85-90 \%$ relative humidity under different atmosphere pressures.

considered rotten. The severity of fruit decay was expressed as percentage of fruit showing decay symptoms. Skin colour of 20 fruit from each replicate was measured using a colorimeter (Konica Minolta, CR-400, Japan) with a 6-mm aperture size, which provided $L^{*}$ and $a^{*}$ values according to the system established by the Commission Internationale de L'Eclairage (CIE, International Commission on Illumination). A reference white tile was used for calibration.

\section{Measurements of respiration and ethylene production rates}

Ten fruit were enclosed in $250 \mathrm{~mL}$ glass jars at $5^{\circ} \mathrm{C}$ for $2 \mathrm{~h}$ and then $2 \mathrm{~mL}$ of headspace gas were taken from each jar. $\mathrm{CO}_{2}$ amount was measured by gas chromatography (Rainbow, SP-9890, China) equipped with flame ionization detector and a packed column (GDX-502, Zhonghuida Inc., China). Ethylene concentration was analysed by gas chromatography using a flame ionization detector. Respiration and ethylene production rates were expressed as $\mathrm{mg}$ $\mathrm{CO}_{2}$ and $\mu \mathrm{g}$ per hour on fresh weight basis, respectively.

\section{Measurements of total soluble solids and titratable acidity}

Fifty fruit from each treatment were taken. Juice was obtained by a juicer (HR1861, Philips Co. Beijing, China), followed by filtration through cheesecloth. The juice was analyzed for total soluble solids (TSS) and titratable acidity (TA). TSS concentration was determined by a portable refractometer (Atago PAL-1, Japan) while TA content was measured by titrating $20 \mathrm{~mL}$ of the juice to $\mathrm{pH} 8.2$ using $0.1 \mathrm{~mol} \mathrm{~L}^{-1} \mathrm{NaOH}$.

\section{MDA content determination}

MDA content was determined according to the method described by Li et al. [14] with some modification. Fruit tissues ( $1 \mathrm{~g}$ ) were extracted for $2 \mathrm{~h}$ with $5 \mathrm{~mL}$ of trichloroacetic acid (10\%). Three milliliters of $0.5 \%$ thiobarbituric acid (TBA) in 10\% trichloroacetic acid were added to $1 \mathrm{~mL}$ of the extract. The solution was heated in a boiling water bath for $20 \mathrm{~min}$, then immediately cooled, and finally centrifuged at $6000 \times \mathrm{g}$ for $10 \mathrm{~min}$ to clarify the solution. Absorbance was measured at 532 and $600 \mathrm{~nm}$. MDA content was expressed as $\mu \mathrm{mol} / \mathrm{g}$ FW by the method of Li et al. [14].

\section{Enzymatic activity assay}

Five grams of fruit tissues were homogenized in $25 \mathrm{~mL}$ of $100 \mathrm{mmol} \mathrm{L}^{-1}$ Tris- $\mathrm{HCl}$ buffer $(\mathrm{pH} 7.8)$ containing 2 mmol L ${ }^{-1}$ EDTA and $2 \mathrm{mmol} \mathrm{L}^{-1} 1$,4-dithiothreitol at $4^{\circ} \mathrm{C}$. The homogenate was centrifuged at $15,000 \times \mathrm{g}$ for $15 \mathrm{~min}$ at $4^{\circ} \mathrm{C}$, and then the supernatant was collected for the enzymatic activity assay. Protein was measured according to the method of Bradford [26], using bovine serum albumin (BSA) as the standard.

CAT was analyzed according to the method of Beers \& Sizer [27] with some modifications. The disappearance of $\mathrm{H}_{2} \mathrm{O}_{2}$ was monitored by measuring the decrease in absorbance at $240 \mathrm{~nm}$ of a reaction mixture containing $100 \mathrm{mmol} \mathrm{L}^{-1}$ Tris- $\mathrm{HCl}$ buffer ( $\mathrm{pH} 7.8$ ), $25 \mathrm{mmol} \mathrm{L}^{-1}$ $\mathrm{H}_{2} \mathrm{O}_{2}$, and $0.2 \mathrm{~mL}$ of crude enzyme extract. One unit of enzymatic activity was defined as 0.01 change of absorbance at $240 \mathrm{~nm}$ per minute. Specific CAT activity was expressed as units per mg protein. POD activity was assayed according to the method described by Yang et al. [10]. The reaction mixture $(2 \mathrm{~mL})$ consisted of 50 mmol L ${ }^{-1}$ sodium phosphate buffer ( $\mathrm{pH}$ 6.5), $6 \mathrm{mmol} \mathrm{L}^{-1}$ guaiacol and $4.5 \mathrm{mmol} \mathrm{L}^{-1} \mathrm{H}_{2} \mathrm{O}_{2}$ prior to the addation of $1 \mathrm{~mL}$ of crude enzyme extract. Increase in absorbance at $470 \mathrm{~nm}$ at intervals of $30 \mathrm{~s}$ was recorded. One unit of enzymatic activity was defined as the amount of enzyme that catalyzed the peroxidation of $1 \mathrm{mmol}$ of guaiacol per minute. Specific POD activity was expressed as units per mg protein.

\section{Total phenolic content determination}

One gram of lyophilized fruit tissues was extracted with $25 \mathrm{~mL}$ of ethanol for $3 \mathrm{~h}$. Total phenolic contents were 
estimated colourimetrically using the Folin-Ciocalteu method [28]. The extract was appropriately diluted, and then $1 \mathrm{~mL}$ of the dilution was oxidized with $0.5 \mathrm{~mL}$ of Folin-Ciocalteau reagent. The reaction was neutralized with $5 \mathrm{ml}$ of $5 \% \mathrm{Na}_{2} \mathrm{CO}_{3}$. The solution was immediately diluted to a final volume of $25 \mathrm{~mL}$ with distilled water and then mixed thoroughly. The absorbance was read at $765 \mathrm{~nm}$ after 1 hour of incubation in dark at $25^{\circ} \mathrm{C}$ using a spectrophotometer (Shimadzu UV-2550, Japan). Gallic acid was used as a standard, and phenolic contents were expressed as mg gallic acid equivalents (GAE)/g FW.

\section{FRAP assay}

The ferric reducing ability of the Chinese bayberry was measured according to the method of Benzie \& Strain [29]. To prepare the FRAP reagent, a mixture of $0.3 \mathrm{~mol}$ $\mathrm{L}^{-1}$ acetate buffer ( $\mathrm{pH} 3.6$ ), $10 \mathrm{mmol} \mathrm{L}^{-1}$ tripyridyltriazine (TPTZ), and $20 \mathrm{mmol} \mathrm{L}^{-1}$ ferric chloride (10:1:1, $\mathrm{v} / \mathrm{v} / \mathrm{v})$ was made. One gram of lyophilized fruit tissues was extracted for 12 hours with $20 \mathrm{~mL}$ of ethanol. The FRAP reagent $(3.9 \mathrm{~mL})$ was added to the extract solution sample $(0.1 \mathrm{~mL})$ and then mixed thoroughly. The reaction was then monitored for $10 \mathrm{~min}$ at $37^{\circ} \mathrm{C}$ and the absorbance was recorded at $593 \mathrm{~nm}$ on the Shimadzu UV-2550 spectrophotometer. The ferric reducing ability of the Chinese bayberry fruit was expressed as $\mathrm{mmol} \mathrm{FeSO}_{4}$ per litre crude extract.

\section{Data analysis}

All samples were prepared and analysed in triplicate. Statistical analysis was done with one-way analysis of variance using the SAS statistical software package.

\section{Conclusions}

Previous studies indicated that hypobaric storage reduced commodity respiration and prevented wilting and senescence during storage $[17,30]$. In the present study, application of hypobaric pressure to the Chinese bayberries significantly reduced fruit decay and loss in total acids, inhibited respiratory rate, decreased MDA accumulation and maintained total phenolic content, antioxidant capacity and CAT and POD activities. These data suggested that hypobaric storage could be an effective technology in maintaining postharvest quality and prolonging shelf life of Chinese bayberry fruit.

\section{Competing interests}

The authors declare that they have no competing interests.

\section{Authors' contributions}

$\mathrm{HC}$ made a significant contribution to acquisition of data, and data analysis. HY made a substantial contribution to data analysis and manuscript preparation. HG made a significant contribution to experimental design and data analysis. JL made a contribution to acquisition of data, and data analysis. FT and XF participated in some experiments. YJ made a significant contribution to experimental design, data analysis and manuscript revision. All authors read and approved the final manuscript.

\section{Acknowledgements}

The work was supported by the National High Technology Research and Development Program of China (863 Program) (grant No. 2012AA101606) The International Cooperation Project of China (grant No. 2013DFA31450) Special Fund for Agro-scientific Research in the Public Interest (grant No. 201303073) and The International Cooperation Project of the Science and Technology Department of Zhejiang Province, China (grant No. 2011C14003).

\section{Author details}

${ }^{1}$ Food Science Institute, Zhejiang Academy of Agricultural Sciences, Hangzhou 310021, China. ${ }^{2}$ School of Life \& Environmental Sciences, Wenzhou University, Wenzhou 325035, China. ${ }^{3}$ South China Botanical Garden, Chinese Academy of Sciences, Guangzhou 510650, China.

Received: 15 November 2012 Accepted: 10 January 2013

Published: 14 January 2013

\section{References}

1. Chen K, Xu C, Zhang B, Ferguson IB: Red bayberry: Botany and horticulture. Horticultural Reviews 2004, 30:83-114.

2. Li ZL, Zhang SL, Chen DM: Red bayberry (Myrica rubra Seib \& Zucc.): A valuable evergreen tree fruit for tropical and subtropical areas. Acta Horticulturae 1992, 321:112-121.

3. Fang Z, Zhang Y, Lü Y, Ma G, Chen J, Liu D, Ye X: Phenolic compounds and antioxidant capacities of bayberry juices. Food Chem 2009, 113:884-888,

4. Bao JS, Cai YZ, Sun M, Wang G, Corke H: Anthocyanins, flavonols, and free radical scavenging activity of chinese bayberry (Myrica rubra) extracts and their color properties and stability. J Agric Food Chem 2005, 53:2327-2332.

5. Zhang W, Li X, Zheng J, Wang G, Sun C, Ferguson I, Chen K: Bioactive components and antioxidant capacity of Chinese bayberry (Myrica rubra Sieb. and Zucc.) fruit in relation to fruit maturity and postharvest storage. Eur Food Res Technol 2008, 227:1091-1097.

6. Wang $\mathrm{K}, \mathrm{Cao} \mathrm{S}$, Jin $\mathrm{P}$, Rui $\mathrm{H}$, Zheng $\mathrm{Y}$ : Effect of hot air treatment on postharvest mould decay in Chinese bayberry fruit and the possible mechanisms. Int J Food Microbiol 2010, 141:11-16.

7. Zhang W, Chen K, Zhang B, Sun C, Cai C, Zhou C, Xu W, Zhang W, Ferguson IB: Postharvest responses of Chinese bayberry fruit. Postharvest Biol Technol 2005, 37:241-251.

8. Yang Z, Zheng Y, Cao S, Tang S, Ma S, Li N: Effects of storage temperature on the textural, properties of Chinese bayberry fruit. J Texture Stud 2007, 38:166-177.

9. Zheng $Y$, Yang Z, Chen X: Effect of high oxygen atmospheres on fruit decay and quality in Chinese bayberries, strawberries and blueberries. Food Control 2008, 19:470-474.

10. Yang $Z$, Zheng $Y$, Cao S: Effect of high oxygen atmosphere storage on quality, antioxidant enzymes, and DPPH-radical scavenging activity of Chinese Bayberry fruit. J Agric Food Chem 2009, 57:176-181.

11. Luo $Z, X u T$, Xie J, Zhang $L, X i$ Y: Effect of hot air treatment on quality and ripening of Chinese bayberry fruit. J Sci Food Agric 2009, 89:443-448.

12. Wang $K$, Jin P, Tang S, Shang H, Rui H, Di H, Cai Y, Zheng Y: Improved control of postharvest decay in Chinese bayberries by a combination treatment of ethanol vapor with hot air. Food Control 2011, 22:82-87.

13. Giri A, Osako K, Ohshima T: Effects of hypobaric and temperaturedependent storage on headspace aroma-active volatiles in common squid miso. Food Res Int 2011, 44:739-747.

14. Li W, Zhang M, Yu H: Study on hypobaric storage of green asparagus. J Food Eng 2006, 73:225-230.

15. Dilley DR: Hypobaric storage of perishable commodities - fruits, vegetables, flowers and seedlings. Acta Horticulturae 1977, 62:61-70.

16. Romanazzi G, Nigro F, Ippolito A: Short hypobaric treatments potentiate the effect of chitosan in reducing storage decay of sweet cherries. Postharvest Biol Technol 2003, 29:73-80.

17. Chen W, Gao H, Chen H, Mao J, Song L, Ge L: Effects of hypobaric storage on postharvest physiology and quality of flesh-melting textured juicy peach. Trans Chin Soc Agric Mach 2010, 41(9):108-112 (in Chinese). 
18. Burg SP: Postharvest physiology and hypobaric storage of fresh produce. Wallingford, UK: CABl; 2004.

19. Romanazzi G, Nigro F, Ippolito A, Salerno M: Effect of short hypobaric treatments on postharvest rots of sweet cherries, strawberries and table grapes. Postharvest Biol Technol 2001, 22:1-6.

20. Corey KA, Bates ME, Adams SL: Carbon dioxide exchange of lettuce plants under hypobaric conditions. Adv Space Res 1996, 18:265-272.

21. An DS, Park E, Lee DS: Effect of hypobaric packaging on respiration and quality of strawberry and curled lettuce. Postharvest Biol Technol 2009, 52:78-83.

22. He C, Davies FT, Lacey RE, Drew MC, Brown DL: Effect of hypobaric conditions on ethylene evolution and growth of lettuce and wheat. J Plant Physiol 2003, 160:1341-1350.

23. Hodges DM, Lester GE, Munro KD, Toivonen PTA: Oxidative stress: importance for postharvest quality. HortScience 2004, 39:924-929.

24. Fang ZX, Zhang M, Wang LX: HPLC-DAD-ESIMS analysis of phenolic compounds in bayberries (Myrica rubra Sieb. et Zucc). Food Chem 2007, 100:845-852.

25. Rice-Evans CA, Miller NJ, Paganga G: Structure antioxidant activity relationships of flavonoids and phenolic acids. Free Radic Biol Med 1996, 20:933-956.

26. Bradford MM: A rapid and sensitive method for the quantitation of microgram quantities of protein utilizing the principle of protein-dye binding. Anal Biochem 1976, 72:248-254.

27. Beers RF Jr, Sizer IW: A spectrophotometric method for measuring the breakdown of hydrogen peroxide by catalase. J Biol Chem 1952, 195:133-140.

28. Sigleton VL, Orthofer R, Lamuela-Raventos RM: Analysis of total phenols and other oxidation substrates and antioxidants by means of FolinCiocalteu reagent. Methods Enzymol 1999, 299:152-178.

29. Benzie IF, Strain JJ: The ferric reducing ability of plasma (FRAP) as a measure of "antioxidant power": The FRAP assay. Anal Biochem 1996, 239:70-76.

30. Jiao S, Johnson JA, Fellman JK, Mattinson DS, Tang J, Davenport TL, Wang S: Evaluating the storage environment in hypobaric chambers used for disinfesting fresh fruits. Biosyst Eng 2012, 111:271-279.

Cite this article as: Chen et al.: Effect of hypobaric storage on quality, antioxidant enzyme and antioxidant capability of the Chinese bayberry fruits. Chemistry Central Journal 2013 7:4.

\section{Publish with ChemistryCentral and every scientist can read your work free of charge \\ "Open access provides opportunities to our colleagues in other parts of the globe, by allowing anyone to view the content free of charge." \\ W. Jeffery Hurst, The Hershey Company. \\ - available free of charge to the entire scientific community \\ - peer reviewed and published immediately upon acceptance \\ - cited in PubMed and archived on PubMed Central \\ - yours - you keep the copyright \\ Submit your manuscript here: \\ http://www.chemistrycentral.com/manuscript/<smiles>c1ccccc1</smiles> \\ ChemistryCentral}

